\title{
CASTLES AS A TOURIST CULTURAL PRODUCT IN THE PROVINCE OF ALICANTE (SPAIN): ACTIONS, INITIATIVES AND PROPOSALS
}

\author{
JUAN ANTONIO MIRA RICO \\ ICOMOS-ICOFORT, Castalla Municipal Service for Cultural Heritage, Spain
}

\begin{abstract}
The province of Alicante has an important number of castles. Their existence is the result of many historical dynamics, as part of al-Andalus, first, and of the crowns of Aragon and Castile, later. In 2016, during the 3rd International Conference on Defence Sites: Heritage and Future, it was explained how municipalities manage their castles in the province of Alicante - a subject developed in the doctoral thesis undertaken at the University of Alicante between 2013 and 2016. This management will be analysed in depth, taking advantage of the opportunity that the 15th International Conference on Studies, Repairs and Maintenance of Heritage Architecture offers. Departing from a sample of 47 fortifications, their role as a tourist cultural product will be studied in two different ways: determining what actions are carried in these castles - like the implementation of guided and/or self-guided visits with a stable schedule, the accomplishment of open days, as well as dramatized visits, their musealisation, etc. - and which global initiatives, like the Vinalopó Castles Route - carried out by the University of Alicante - or the Costa Blanca 100 Castles Route - a tourist brand of the province of Alicante - are being undertaken by the Provincial Council of Alicante. Finally, in view of the historical and heritage interest awakened by these fortifications, some management proposals focused on their use as heritage resources, with a great potential, capable of being transformed into tourist cultural products of quality will be explained.
\end{abstract}

Keywords: castles, province of Alicante, tourist cultural product, Vinalopó Castles Route, Costa Blanca 100 Castles Route.

\section{INTRODUCTION}

As it has already been explained in a previous study [1], the historical vicissitudes of the province of Alicante, an administrative division belonging to the Valencian Community - one of the seventeen autonomous communities that make up Spain (Fig. 1) - have promoted the existence of a large number of castles from north to south, and from east to west of the province.

Many of these fortifications, specifically 43 of municipal property, were studied regarding to their management at the beginning of the 21 st century. This is a project that complements the traditional historical research - archaeological, architectural and documental - on fortifications: from seven groups according to the population of the municipalities where they are located, $12(27.91 \%)$ have not been managed, $19(44.18 \%)$ have been managed punctually - at least one action has been made - and 12 (27.91\%) have been managed continuously actions have been made from time to time.

Taking into account the work carried out previously, the present research will point out municipal castles with requirements to be considered as a cultural tourist product, analysing their role in two levels. Firstly, like a microscale based on knowing those actions developed in fortifications; and secondly, as a macroscale focused on larger initiatives like the Vinalopó Castles Route or the Costa Blanca 100 Castles Route. Proposals improving their management also will be explained in order to make easier their use as a tourist cultural product. This is a fundamental aspect due to the interest that castles arouse in society, as well as their tourist role in the province of Alicante under the Costa Blanca brand [2]. 


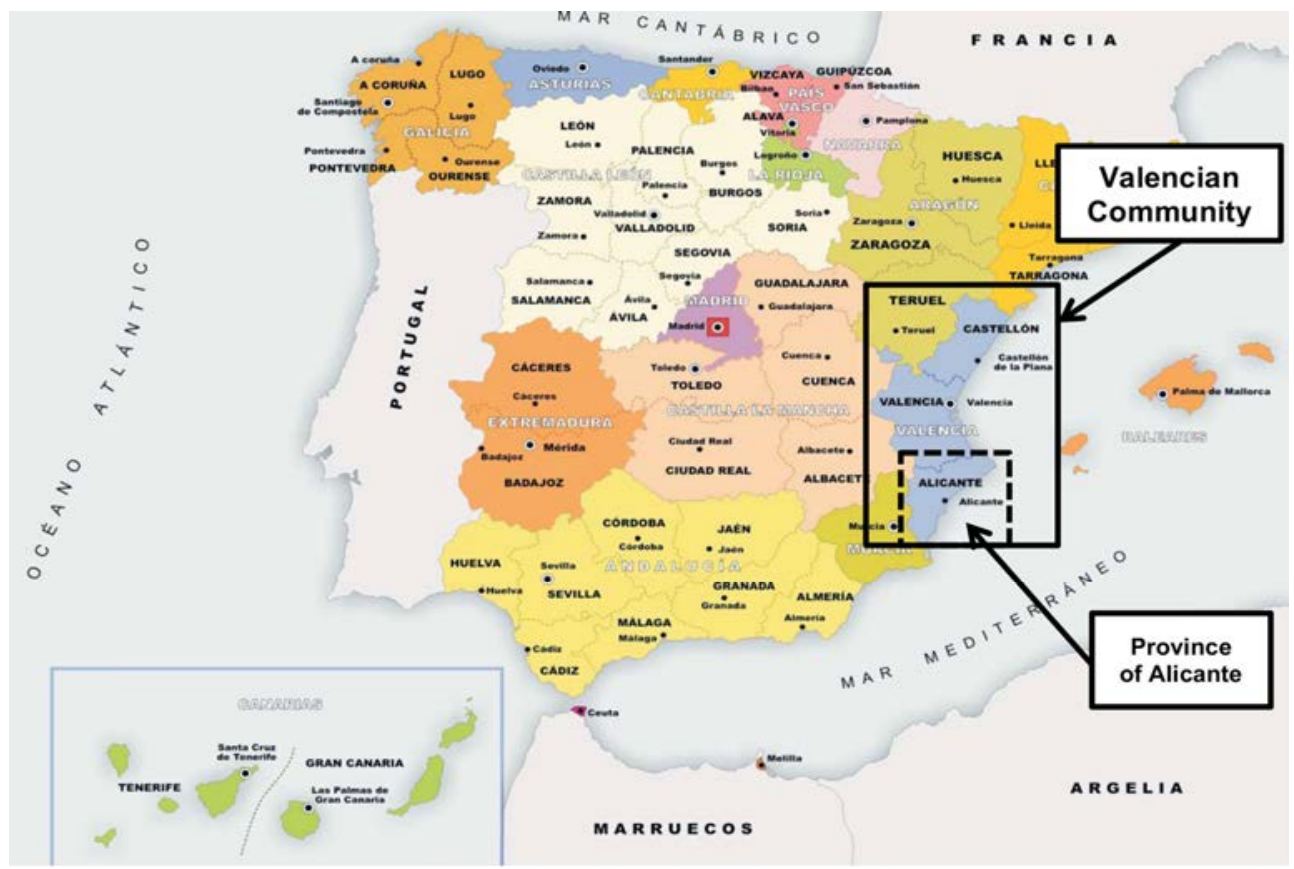

Figure 1: Location of the province of Alicante in the Iberian Peninsula. (Source: http://www.mecd.gob.es/dms/consejerias-exteriores/portugal/imagenes/ publicaciones/MAPAPOLITICO/MAPAPOLITICO.jpg)

\section{MUNICIPAL CASTLES OF ALICANTE AS HERITAGE RESOURCES}

Not all of the castles [2] meet the requirements to become a cultural tourist product because of their state of preservation and the lack of interpretative tools. Thus, paying attention to fortifications that present a good and/or acceptable state of preservation, the result is a set of fourteen castles that, as heritage resources, may be transformed into a cultural tourist product: Atalaya Castle (Villena) (1), Banyeres de Mariola Castle (Banyeres de Mariola) (2), Biar Castle (Biar) (3), Castalla Castle (Castalla) (4), Cocentaina Castle (Cocentaina) (5), Dénia Castle (Dénia) (6), Guadalest Castle (Castell de Guadalest) (7), Guardamar del Segura Castle (Guardamar del Segura) (8), Mola Castle (Novelda) (9), Penella Castle (Cocentaina) (10), Petrer Castle (Petrer) (11), Santa Bárbara Castle (Alicante) (12), Santa Bárbara Castle (Cox) (13) and Sax Castle (Sax) (14) (Fig. 2). This situation is certainly poor: $29.79 \%$ of municipal castles in the province of Alicante.

On the other hand, without addressing their architectural characteristics, morphological configuration and historical evolution seen in other works [3]-[9], it is necessary to point out the following questions.

Firstly, the most part of the fortifications are located in small and medium-sized municipalities inside the province as Villena, Banyeres de Mariola, Biar, Castalla, etc. However, they are beside A-31 and A-7 highways, and AP-7 motorway, fundamental to visit them. 


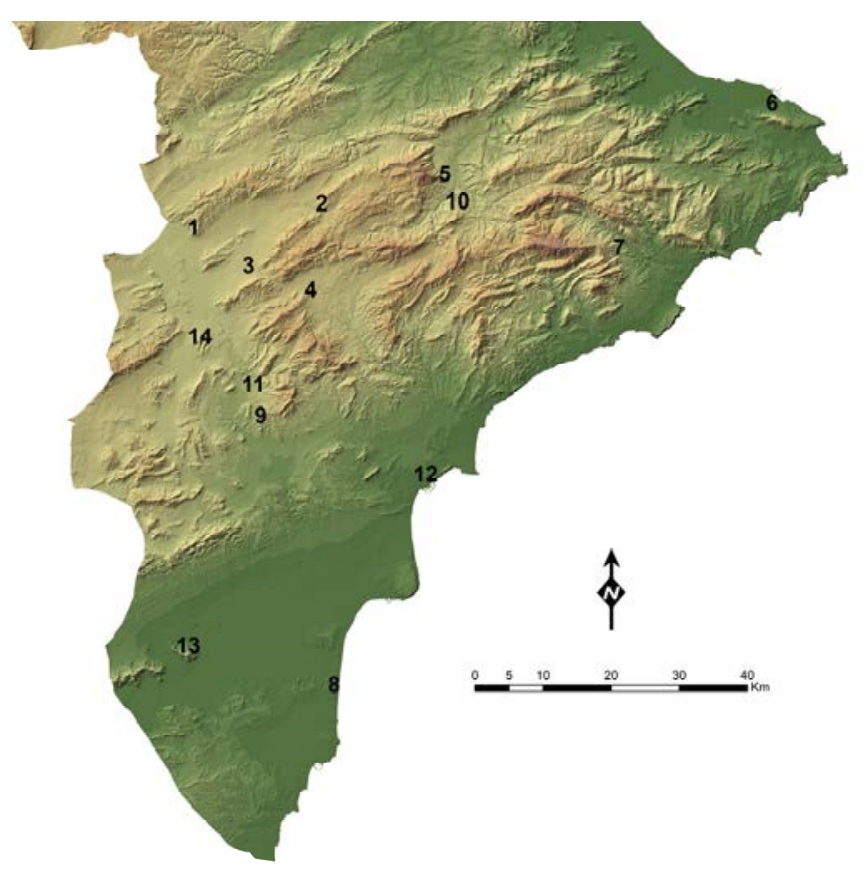

Figure 2: Location of the castles. (Source: own preparation from the picture of Juan José Mataix Albiñana.)

Secondly, it deals with castles managed continuously over time $(85.71 \%)$, such as Atalaya Castle, Banyeres de Mariola Castle, Biar Castle, Castalla Castle, Cocentaina Castle, Dénia Castle, Mola Castle, Penella Castle, Petrer Castle, Santa Bárbara Castle (Alicante) and Sax Castle. While Guadalest Castle, Guardamar del Segura Castle and Santa Bárbara Castle (Cox) were managed punctually in terms of financial resources.

\section{MUNICIPAL CASTLES OF ALICANTE AS A TOURIST CULTURAL PRODUCT}

In order to know if these fortifications can really be considered a cultural tourist product, it is opportune to systematise the information available on specific actions and general initiatives. The first ones are focused on fortifications, while the rest are general and encompass a few castles.

Within the group of actions, the following variables will be assessed: physical accessibility, intellectual accessibility (equipment or explanatory material and/or musealisation), opening hours to the public, guided and/or self-guided visits, presence on the network and support infrastructures.

In terms of initiatives, Vinalopó Castles Route and Costa Blanca 100 Castles Route will be analysed.

\subsection{Specific actions}

Taking into account that castles have not been built to be visited, most of the fortifications included in this work have a poor physical accessibility. Atalaya Castle, Dénia Castle, Guadalest Castle, Guardamar del Segura Castle, Mola Castle, Santa Bárbara Castle 
(Alicante) and Sax Castle are fortifications without accessibility for all public: they have ramps, narrow doors, steps, etc.; although it is possible to arrive by car. On the contrary, Castalla Castle, Cocentaina Castle, Penella Castle, Petrer Castle, and Santa Bárbara Castle (Cox) have both absence of accessibility and impossibility of arriving by car.

As for intellectual accessibility and taking as reference some previous works [10], most of the fortifications are partly/completely musealised or have explanatory equipment (Table 1) - except Guadalest Castle, Mola Castle and Santa Bárbara Castle (Cox).

As it can be seen in Table 1, castles have a traditional musealisation. It is based on the primacy of the object for specialists exposing the role of the visitor. On the other hand, the interactive musealisation favours an active participation of the visitor: accessible for all, more didactic, with resources to make the contents known. Both models have advantages and disadvantages [11], but the best is to take a chance on a musealisation for all, not only for specialists. In this sense, interactive museography outpaces the traditional one. In the case of castles that are not musealised, Guadalest Castle has explanatory panels, while Santa Bárbara Castle (Cox) lacks both musealisation and panels.

With respect to the opening hours, most of the fortifications have a regular schedule except: Cocentaina Castle, whose key must be asked for at the police station; Guadalest Castle, that can be visited anytime; Guardamar del Segura, that can also be visited anytime because it does not have a door; Penella Castle (Cocentaina), that opens punctually; and Santa Bárbara Castle (Cox), whose key must be asked for at the city council. The existence of a regular schedule is better and more professional than lending the key at the police station or city council. It must be said that visits are free, save in Banyeres de Mariola Castle, Castalla Castle and Dénia Castle, where they are paid.

Table 1: Musealised castles and/or explanatory equipment. (Source: J.A. Mira Rico, in press, updated.)

\begin{tabular}{|l|l|l|}
\hline $\begin{array}{l}\text { Musealised castles and/or } \\
\text { with explanatory equipment }\end{array}$ & \multicolumn{1}{|l|}{$\begin{array}{l}\text { Types of musealisation and/or } \\
\text { explanatory equipment }\end{array}$} & \multicolumn{1}{l}{$\begin{array}{l}\text { Musealisation topics and/or } \\
\text { explanatory equipment }\end{array}$} \\
\hline Atalaya Castle (Villena) & $\begin{array}{l}\text { Traditional with interactive } \\
\text { components/complete }\end{array}$ & Historical/on castle \\
\hline Biar Castle & Traditional/partial & Historical/on castle \\
\hline Banyeres de Mariola Castle & Traditional/complete & $\begin{array}{l}\text { Anthropological/on Moors } \\
\text { and Christians town festival }\end{array}$ \\
\hline Castalla Castle & $\begin{array}{l}\text { Traditional with interactive } \\
\text { components/partial }\end{array}$ & Historical/on castle \\
\hline Cocentaina Castle & Traditional/complete & Historical/on castle \\
\hline Dénia Castle & Traditional/complete & $\begin{array}{l}\text { Historical/on castle and } \\
\text { municipality }\end{array}$ \\
\hline Guardamar del Segura Castle & $\begin{array}{l}\text { Traditional, with interactive } \\
\text { components/partial }\end{array}$ & Historical/on castle \\
\hline Penella Castle (Cocentaina) & Traditional/complete & Historical/on castle \\
\hline Petrer Castle & Traditional/partial & Historical/on castle \\
\hline $\begin{array}{l}\text { Santa Bárbara Castle } \\
\text { (Alicante) }\end{array}$ & $\begin{array}{l}\text { Traditional, with interactive } \\
\text { components/complete }\end{array}$ & $\begin{array}{l}\text { Historical/on castle and } \\
\text { municipality }\end{array}$ \\
\hline Sax Castle & Traditional/partial & $\begin{array}{l}\text { Historical/on castle and } \\
\text { municipality }\end{array}$ \\
\hline
\end{tabular}


Other key aspect in order to talk about a tourist product is what type of visits exist in these fortifications. Guided visits are present in Atalaya Castle, Banyeres de Mariola Castle, Castalla Castle, Dénia Castle, Guadalest Castle, Mola Castle, Petrer Castle, Santa Bárbara Castle (Alicante) and Sax Castle. In addition, these may be developed as activities of living history in Atalaya Castle, Dénia Castle and Santa Bárbara Castle (Alicante). Meeting adequate quality criteria, these visits are very attractive for all types of public because they are not usual in Spain, unlike in the Anglo-Saxon countries. On the other hand, self-guided visits are carried out in Banyeres de Mariola Castle, Biar Castle, Dénia Castle, Guadalest Castle, Guardamar del Segura Castle, Mola Castle, Penella Castle (when it is open), Santa Bárbara Castle (Alicante) and Santa Bárbara Castle (Cox). The main handicap is that visitors can be lost if castles are not musealised and do not have enough explanatory equipment, such as panels or audio guides.

Nowadays, any tourist product should be seen online because information on castles can be found in the network. If attention is focused on city council official pages, all of them include information. It is only scarce in Guadalest Castle, Guardamar del Segura Castle and Petrer Castle. Moreover, most of the contents are in other languages, besides the official ones of the Valencian Community: such as Atalaya Castle in Chinese; Banyeres de Mariola Castle in English; Castalla Castle in English and French; Dénia Castle in English, French and German; Guadalest Castle in English; Mola Castle in English, German, Dutch, French, Norwegian and Russian; and Santa Bárbara Castle (Cox) in English. Biar Castle, Cocentaina Castle, Penella Castle, Petrer Castle and Santa Bárbara Castle (Alicante) only have information in Spanish and Valencian, a fact that can difficult their search. Guardamar del Segura Castle and Sax Castle only have information in Spanish. Logically, other web pages offer information about them, although they are not always updated.

Finally, additional infrastructures are also a key element considering fortifications as a cultural tourist product. Atalaya Castle, Banyeres de Mariola Castle, Cocentaina Castle, Dénia Castle, Guardamar del Segura Castle, Mola Castle, Penella Castle, Petrer Castle and Santa Bárbara Castle (Alicante) have infrastructures in the form of tourist offices and reception/interpretation centres, where visitors can find information. Likewise, they offer accommodation, leisure and catering: very extensive in Dénia Castle and Santa Bárbara Castle (Alicante) because they are located in coastal municipalities with a lot of tourism, and modest in Banyeres de Mariola Castle. Nevertheless, Santa Bárbara Castle (Cox) and Sax Castle have not any type of infrastructure. In conclusion, this lead group have different cultural infrastructures represented by different archaeological and/or historical museums, such as José María Soler Archaeological Museum (Atalaya Castle) or Novelda Archaeological Museum (Mola Castle) with contents that complement their visits.

\subsection{General initiatives}

The Vinalopó Castles Route [12] is a project undertaken by the Institute of Tourism Research (University of Alicante), with the support of the Costa Blanca Provincial Tourist Board, dependent on the Provincial Council of Alicante. It intends to "(...) lay the foundations for the definitive boost of a key factor on the Costa Blanca territorial tourism structure, departing from the creation of a possible Club of a Cultural Tourist Product and being able to invigorate an emblematic route for Alicante: Vinalopó Castles Route".

This route is based on a geographical landmark: the River Vinalopó and its near lands, that were part of the border between the crowns of Aragon and Castile with a high number of castles. The route includes the following municipalities with their fortifications and palaces: Banyeres de Mariola (Banyeres de Mariola Castle), Biar (Biar Castle), Castalla (Castalla Castle), Villena (Atalaya Castle), Sax (Sax Castle), Elda (Elda Castle), Petrer 
(Petrer Castle), Novelda (Mola Castle), Elche (Altamira Palace), Santa Pola (Santa Pola Fortress) and Onil (Onil Palace). It must be noted that Castalla Castle and Onil Palace belong to the Foia de Castalla district, not Vinalopó district.

However, the route has not gone beyond being present on the Internet and in different tourism fairs, such as FITUR, and the edition of a tourist brochure with historical and interesting information in Spanish and English - schedules, prices, etc. Currently, any action has been taken to make it a true tourist product, since there are some castles that do not meet the conditions to be visited with reference to infrastructures and equipment. They do not have any interpretation centre showing the characteristics of the route and offering common and/or interrelated content, with a common management policy in order to maintain quality standards over time, and there are no regular meetings among member municipalities. In addition, its contents are only in Spanish, a fact that reduces the reach to potential visitors who do not speak and/or understand the language. Therefore, in order to make this route work, there must be more active participation of the municipalities, as well as of the Provincial Council of Alicante and Valencian government (Generalitat Valenciana). It could be also extended to other provinces and/or autonomous communities based on the historic border between the crowns of Aragon and Castile.

The participation of the Provincial Council of Alicante, through its Costa Blanca Provincial Tourist Board, has turned the Vinalopó Castles Route into the Costa Blanca 100 Castles Route [13] including the following routes: Vinalopó Castles, that does not coincide with the original because Onil Palace lacks, although other castles are included; Key of the Kingdom Castles; Tudmir Castles; Mountain Castles and Border of Fear Castles. Moreover, this new route follows the same pattern as its predecessor in terms of presence on the Internet, etc. [14]. Likewise, no actions have been carried out to improve the condition of castles, fortresses, palaces and towers. Nevertheless, contents can be found in many languages: Spanish, Valencian, English, French, German and Russian.

\subsection{Proposals}

This point is about actions to achieve, improve and enhance the role of municipal castles as a cultural tourist product.

The Costa Blanca 100 Castles Route includes fortresses (Santa Pola), walls (Vila Joiosa and Calp), palaces (Elche and Onil), and interior and coastal towers (Campello and Torre de les Maçanes). Thus, the name Costa Blanca 100 Castles Route does not seem the most appropriate since it contains other constructions that are not castles. In order to avoid misunderstandings and exclusions, a new, more inclusive name is needed, for example: Costa Blanca Castles, Fortresses, Palaces and Towers.

On the other hand, the name of the subroutes must be taken into account. These are called with precise geographical terms - Vinalopó Castles because it is a river that crosses part of the province of Alicante - and imprecise terms - Mountain Castles - along with defined historical terms - Tudmir Castles - and less defined terms - Key of the Kingdom Castles and new coined terms - Border of Fear Castles. In respect of historical names, there are few contradictions: Tudmir Castles [15] encompasses some assets as the Horadada Tower (Pilar de la Horadada), which surpass the chronological framework of that territory. In addition, it must be added some indefinite terms, like Key of the Kingdom because it does not specify the kingdom; and Border of Fear, corresponding to landmarks located on the coast and object of some corsair attacks. A new name is also necessary to avoid possible misunderstandings, for example a definition of the subroutes on identifiable and non-confusing geographical criteria in comparison with current names (Table 2): 
Table 2: Names and proposals for the Costa Blanca 100 Castles Route. (Source: J.A. Mira Rico.)

\begin{tabular}{|c|c|}
\hline Subroutes names & Proposed names \\
\hline Vinalopó Castles & Vinalopó Castles \\
\hline Mountain Castles & Mountain Castles \\
\hline Tudmir Castles & Segura Castles \\
\hline Key of the Kingdom & Coastal Castles \\
\hline Border of Fear Castles & . \\
\hline
\end{tabular}

Beyond their reduction from five to four, the change would also involves a reorganisation of castles, fortresses, palaces and towers assigned to each subroute and adjusting them to the geographical reality. In this sense, Castalla Castle and Banyeres de Mariola Castle would be part of the Mountain Castles; while those of the Key of the Kingdom Castles would be part of the Coastal Castles - except New Tabarca Island, being part of the Vinalopó Castles.

It is also important to indicate the conditions of each asset in order to be classified into several categories, according to their consideration as a cultural tourist product. In this way, visits could be prioritised avoiding a waste of time because there are not explanatory panels or their state of preservation constitutes a danger.

Likewise, it would be necessary to equip the route with infrastructure to work with interpretation centres, making known its characteristics and those of the assets in it, as well as carrying out actions on them. With reference to fortifications, the Provincial Council of Alicante, in collaboration with the city councils and Valencian government (Generalitat Valenciana), should opt for a direct intervention to initiate, improve and enhance them as a cultural tourist product. Each fortification has different needs, but in the cases of Biar Castle, Castalla Castle and Sax Castle their role as cultural tourist products must be developed, culminating their musealisation and/or improving the existing explanatory equipment. Others, such as Mola Castle and Santa Bárbara Castle (Cox), need to start their role as cultural tourist products, with their musealisation and the installation of explanatory equipment that allows to know their history over time. In Guardamar del Segura is essential to improve its state of preservation. With these actions, Atalaya Castle, Biar Castle, Mola Castle, Petrer Castle and Sax Castle could be configured as reference landmarks of the Vinalopó Castles, following the proposal. Castalla Castle, Cocentaina Castle, Guadalest Castle and Penella Castle would be the most outstanding fortifications of the Mountain Castles. Guardamar del Segura Castle and Santa Bárbara Castle (Cox) would be the most important of the Segura Castles, while Dénia Castle and Santa Bárbara Castle (Alicante) would be crucial in the Coastal Castles. As can be seen, there are a lot of interesting working possibilities and content development, as establishing synergies among near castles: Castalla Castle and Sax Castle, that are part of larger entities [16]; or Biar Castle and Villena Castle, whose proximity and historical location in the crowns of Aragon and Castile would make easier the development of joint contents.

\section{FINAL CONSIDERATIONS}

On the previous pages it has been pointed out that the province of Alicante is a privileged territory as far as municipal castles. Despite having a large number, only 14 meet good conditions to be visited. But if a detailed analysis is carried out, 11 could be considered as cultural tourist products: Atalaya Castle, Banyeres de Mariola Castle, Biar Castle, Castalla Castle, Cocentaina Castle, Dénia Castle, Guadalest Castle, Penella Castle, Petrer Castle, Santa Bárbara Castle (Alicante) and Sax Castle. It is still necessary to continue working on 
Guardamar del Segura Castle, Mola Castle and Santa Bárbara Castle (Cox). Therefore, it is a low sample that contrasts with the promotion of castles under the Costa Blanca brand, through the Costa Blanca 100 Castles Route - changing its name to encompass all the heritage elements besides castles. This fact attracts attention because fortifications not prepared to be visited are being promoted. So, it would be interesting to undertake a detailed classification, depending on their qualities as cultural tourist products. In this way, visitors will know if they are going to visit castles with equipment, support infrastructure and offers of leisure, accommodation and catering. They might choose according to their interests. It is a situation that must be revised with direct investments on castles and the creation of equipment, turning them into true cultural tourist products and taking advantage of their potential.

\section{REFERENCES}

[1] Mira Rico, J.A., Management analysis of municipal property castles: fortifications in the province of Alicante (Valencian Community). International Journal of Heritage Architecture. Studies, Repairs and Maintenance, 1(2), 2017. Online https:// www.witpress.com/elibrary/ha-volumes/1/2/1127

[2] Provincial Tourism on the Costa Blanca, Alicante, http://www.costablanca.org/Eng. Accessed on: 15 Dec. 2015.

[3] Segura Herrero, G. \& Simón García, J.L. (coords.), Castillos y torres en el Vinalopó, Centre d'Estudis Locals del Vinalopó: Petrer, 2001.

[4] Menéndez Fueyo, J.L., Bevià i Garcia, M., Mira Rico, J.A. \& Ortega Pérez, J.R. (eds), El Castell de Castalla. Arqueología, arquitectura e historia de una fortificación medieval de frontera, MARQ: Alicante, 2010.

[5] Doménech Faus, E. (coord.), El patrimoni històric i artístic de Cocentaina. La seua recuperació. Les intervencions Arquitectòniques i arqueològiques, Ajuntament de Cocentaina, 2003.

[6] Azuar Ruiz, R., Castellología medieval alicantina: área meridional, Diputación de Alicante: Alicante, 1981.

[7] Varela Botella, S., La restauración del Castillo de Santa Bárbara en Cox. Castells, 5, pp. 43-47, 1995.

[8] Azuar Ruiz, R. \& Navarro Suárez, FC ${ }^{\mathrm{CO}}$ J., Castillos de Alicante, Ediciones Lancia: León, 1995.

[9] Gisbert Santonja, J., Castell de Dénia, Ajuntament de Dénia: Dénia, 2014.

[10] Mira Rico, J.A., Fortificaciones, interactividad y didáctica: el Castell de Castalla como ejemplo teórico en el contexto de la provincia de Alicante. Otarq, 1, pp. 207-226, 2016.

[11] Santacana i Mestre, J. \& Martín Piñol, C. (coords.), Manual de museografía interactiva, Ediciones Trea: Gijón, 2010.

[12] Instituto Universitario de Investigaciones Turísticas, San Vicent del Raspeig, https://www.rutacastillosvinalopo.net. Accessed on: 15 Dec. 2015.

[13] Provincial Tourism on the Costa Blanca, Alicante, http://www.costablanca.org/Eng/ Descubre_la_Costa_Blanca/Ruta\%20de\%20los\%20Castillos/Pages/default.aspx. Accessed on: 15 Dec. 2015.

[14] Provincial Tourism on the Costa Blanca, Alicante, http://www.costablanca.org/ Esp/Descubre_la_Costa_Blanca/Castillos\%20de\%201a\%20Costa\%20Blanca/Docum ents/100\%20Castillos\%20de\%201a\%20Costa\%20Blanca.pdf. Accessed on: 15 Dec. 2015 . 
[15] Región de Murcia Digital, Murcia, http://www.regmurcia.com/servlet/s.Sl?sit=c,373, m,1915\&r=ReP-24811-DETALLE_REPORTAJESPADREs. Accessed on: 15 Dec. 2015.

[16] Mira Rico, J.A., Bevià i Garcia, M. \& Ortega Pérez, J.R., Del Castell de Castalla al Conjunt Patrimonial del Castell de Castalla: un nuevo enfoque en la gestión del patrimonio cultural valenciano. Proceedings of the International Conference on Modern Age Fortifications of the Western Mediterranean Coast Defensive Architecture of the Mediterranean XV to XVIII Centuries, online http://ocs.editorial.upv.es/index.php/FORTMED/FORTMED2015/paper/view/1748 